\title{
Post-harvesting of Solanum paniculatum L. leaves. Part I: Drying kinetics
}

\author{
Elton A. S. Martins ${ }^{1}$, André L. D. Goneli ${ }^{1}$, Alexandre A. Gonçalves ${ }^{1}$, Valdiney C. Siqueira ${ }^{1}$, \\ Claúdia A. L. Cardoso ${ }^{2} \&$ Gabriela L. de Almeida ${ }^{2}$
}

\begin{abstract}
${ }^{1}$ Universidade Federal da Grande Dourados/Faculdade de Ciências Agrárias, Dourados, MS, Brasil. E-mail: eltonmartins@ufgd.edu.br (Corresponding author) - ORCID: 0000-0002-3195-2317; andregoneli@ufgd.edu.br - ORCID: 0000-0001-9963-3497; alexandre_alvesg@hotmail.com - ORCID: 00000002-4772-5135; valdineysiqueira@ufgd.edu.br - ORCID: 0000-0003-3698-0330

${ }^{2}$ Universidade Estadual de Mato Grosso do Sul/Centro de Estudos em Recursos Naturais, Dourados, MS, Brasil. E-mail: claudia@uems.br ORCID:0000-0002-4907-0056; gabriela.lessa19@gmail.com - ORCID: 0000-0002-4175-2693
\end{abstract}

\begin{abstract}
Solanum paniculatum L. (jurubeba) is among the numerous medicinal plants used by the Brazilian population, and the use of its leaves is quite popular, in the form of tea, as a remedy against hangovers after excessive consumption of alcohol and food, besides being used in the form of ointments as healing agent and also in the treatment of liver and digestive problems. Leaves of medicinal plants usually have a high moisture content, requiring its reduction by drying, so that the product can be stored safely until its processing. The objective of this study was to evaluate the drying kinetics of jurubeba leaves and to determine the effective diffusion coefficient and activation energy during drying. Jurubeba leaves were dried at different air temperatures $\left(30,40,50,60\right.$ and $\left.70{ }^{\circ} \mathrm{C}\right)$ and speed $\left(0.4\right.$ and $\left.0.8 \mathrm{~m} \mathrm{~s}^{-1}\right)$. The Midilli model satisfactorily fitted to the observed data of drying of jurubeba leaves for all air conditions. Increasing the drying air temperature and speed reduced the drying time and increased the effective diffusion coefficient. For the air temperature range from 40 to $70^{\circ} \mathrm{C}$, as the drying air speed increases, the activation energy for the drying of the jurubeba leaves is reduced.
\end{abstract}

Key words: Jurubeba, activation energy, air speed, moisture reduction rate, Midilli Model

\section{Pós-colheita de folhas de Solanum paniculatum L. Parte I: Cinética de secagem}

RESUMO: Dentre as inúmeras plantas medicinais utilizadas pela população brasileira está a Solanum paniculatum L. (jurubeba), em que o uso de suas folhas é bastante popular, na forma de chá, como remédio contra ressacas após o consumo exagerado de álcool e comida, além de serem usadas na forma de pomadas como cicatrizantes, e, também, no tratamento de problemas hepáticos e digestivos. As folhas de plantas medicinais, normalmente, possuem elevado teor de água, necessitando a redução do mesmo por meio da secagem, para que o produto possa ser armazenado com segurança até o seu processamento. Objetivou-se com o presente estudo avaliar a cinética de secagem de folhas de jurubeba, bem como determinar o coeficiente de difusão efetiva e a energia de ativação durante a secagem. As folhas de jurubeba foram submetidas a secagem em diferentes temperaturas $\left(30,40,50,60\right.$ e $\left.70{ }^{\circ} \mathrm{C}\right)$ e velocidade do ar $\left(0,4\right.$ e 0,8 $\left.\mathrm{m} \mathrm{s}^{-1}\right)$. O modelo de Midilli ajustou-se satisfatoriamente aos dados observados da secagem das folhas de jurubeba para todas as condições. $\mathrm{O}$ aumento da temperatura e da velocidade do ar de secagem reduziu o tempo de secagem e aumentou o coeficiente de difusão efetiva. Para a faixa de temperatura de 40 a $70{ }^{\circ} \mathrm{C}$, ao aumentar a velocidade do ar de secagem, reduz-se a energia de ativação para a secagem das folhas de jurubeba.

Palavras-chave: jurubeba, energia de ativação, velocidade do ar, taxa de redução de água, modelo de Midilli 


\section{INTRODUCTION}

Solanum paniculatum L. (jurubeba) is a neotropical plant very common in Brazil and other countries such as Paraguay, Bolivia and Argentina, which is used in traditional medicine and for food purposes (Vieira Júnior et al., 2015). Jurubeba is used in traditional medicine in the treatment of liver and digestive problems, for stimulating digestive functions and reducing liver and gallbladder swelling. Thus, jurubeba leaf tea is used as a daily remedy against hangovers after excessive consumption of alcohol and food (Lorenzi \& Matos, 2008). In the ethanol extract of the leaves, the presence of alkaloids, cardiotonic glycosides, tannins, saponins and triterpenes has been identified (Terço \& Lima, 2016).

The drying of leaves of medicinal plants has been studied by several researchers, aiming to provide technical information of this important post-harvest stage for the more efficient processing of these products. Most studies of drying of leaves of medicinal plants evaluate only the effect of different drying air temperatures on the process (Reis et al., 2012; Goneli et al., 2014; Silva et al., 2015; Melo et al., 2016; Silva et al., 2017).

As the quantities of active ingredients contained in the leaves of medicinal plants during the drying process are usually influenced by air temperature and/or the time of exposure to it, the control of drying air speed in the process becomes interesting, since it contributes to the reduction in the time of exposure of the product to drying air, thus reducing the degradation of the active ingredients during the drying process. Thus, some studies have been conducted to evaluate the joint effect of air temperature and speed for the drying of leaves of medicinal plants (Soares et al., 2007; Gasparin et al., 2014; 2017; Karami et al., 2017; Alves et al., 2017; Martins et al., 2018).

In view of the above, the objective of this study was to evaluate the drying kinetics of jurubeba leaves under different drying air temperatures and velocities, statistically fit mathematical models to predict drying curves, and determine the effective diffusion coefficient, moisture reduction rate and activation energy during drying.

\section{Material AND Methods}

The present study was carried out in the Laboratory of PreProcessing and Storage of Agricultural Products, at Faculdade de Ciências Agrárias - FCA, Universidade Federal da Grande Dourados - UFGD, in Dourados, MS, Brazil.

One hundred and fifty jurubeba plants were cultivated, whose seedlings were produced in polystyrene trays, using seeds harvested from the medicinal plant garden of UFGD. Seedlings were transplanted in September 2016 to an experimental area of approximately $500 \mathrm{~m}^{2}$, located at UFGD. For planting the crop and during its development, all necessary cultural practices were carried out, including soil tillage and correction, weed control, irrigation and pest control, for the adequate vegetative growth of plants cultivated until harvest, aiming to obtain a material with homogeneous characteristics. An exsiccate is deposited at UFGD's DDMS Herbarium under the number 5553.

Leaves were randomly collected in the middle and upper thirds in several plants between June and July 2017. Leaves without injury or incidence of diseases were selected in order to guarantee the homogeneity of the physical and chemical characteristics of the product. These leaves were always collected in the morning, avoiding collections of leaves after rainfall or with remnants of dew on the surface, so as not to compromise the characterization of their drying curves.

After each collection, leaves of similar size were selected and their petioles were removed. Before drying, a longitudinal and a transverse cut were made on each leaf, dividing them into four parts, in order to reduce the size so that it was possible to have a uniform layer of leaves on each drying tray of the dryer.

Drying was performed in an experimental fixed-bed dryer (Figure 1). The drying bed was composed of trays with a screened bottom, $0.2 \mathrm{~m}$ in diameter. Approximately $25.6 \mathrm{~g}$ of jurubeba leaves were arranged on each tray of the experimental dryer to form a layer of leaves.

After collection and selection, jurubeba leaves had initial moisture content of approximately 2.76 (decimal, on dry basis - d.b.). Initial and equilibrium moisture contents were determined by the gravimetric method in an oven, at $103 \pm 1$ ${ }^{\circ} \mathrm{C}$, for $24 \mathrm{~h}$ (ASABE, 2010).

For drying tests, the leaves were subjected to four temperatures $\left(40,50,60\right.$ and $\left.70{ }^{\circ} \mathrm{C}\right)$ and two velocities $(0.4$ and $0.8 \mathrm{~m} \mathrm{~s}^{-1}$ ) of the drying air. Drying was performed until they reached the equilibrium moisture content. For statistical modeling purposes, the final moisture content of approximately 0.11 (decimal, d.b.) was considered.

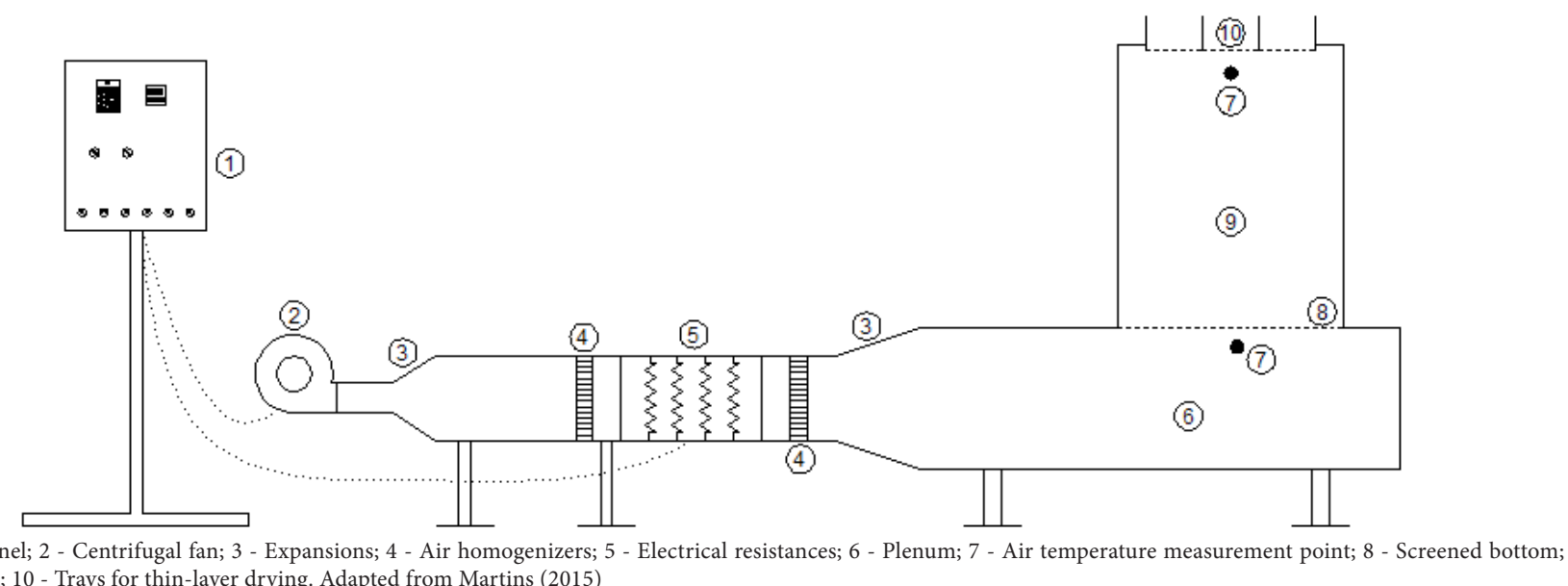

1 - Control panel; 2 - Centrifugal fan; 3 - Expansions; 4 - Air homogenizers; 5 - Electrical resistances; 6 - Plenum; 7 - Air temperature measurement point; 8 - Screened bottom; 9 - Drying bed; 10 - Trays for thin-layer drying. Adapted from Martins (2015)

Figure 1. Experimental dryer used in the drying of jurubeba leaves 
The moisture content of the leaves during the drying tests was determined by the gravimetric method, using a scale with resolution of $0.01 \mathrm{~g}$. During the drying process, the trays with the samples were periodically weighed, with pre-established weighing intervals for the beginning of the process and increased intervals during the process, based on mass difference between successive weighings, avoiding large differences in moisture content between the weighings, knowing the mass and the initial moisture content.

The moisture ratio of jurubeba leaves during drying, under different air conditions, was determined by Eq. 1 .

$$
\mathrm{MR}=\frac{\mathrm{M}-\mathrm{M}_{\mathrm{e}}}{\mathrm{M}_{\mathrm{i}}-\mathrm{M}_{\mathrm{e}}}
$$

where:

MR - moisture ratio of the product, dimensionless;

M - moisture ratio of the product at a certain time, decimal d.b.;

$\mathrm{M}_{\mathrm{e}}$ - equilibrium moisture ratio of the product, decimal d.b.; and,

$M_{i} \quad$ - initial moisture ratio of the product, decimal d.b.

Nonlinear regression models traditionally used to predict the drying of agricultural products (Table 1) were fitted to the moisture ratio data of jurubeba leaves, obtained experimentally during drying. These models have been used by several researchers in studies with medicinal plants (Goneli et al., 2014; Gomes et al., 2017; Gasparin et al., 2017; Alves et al., 2017; Martins et al., 2018).

Table 1. Mathematical models used to estimate the drying kinetics of jurubeba leaves

\begin{tabular}{llc}
\multicolumn{1}{c}{$\begin{array}{c}\text { Model } \\
\text { designation }\end{array}$} & \multicolumn{1}{c}{ Model } & Equation \\
$\begin{array}{l}\text { Approximation } \\
\text { of diffusion }\end{array}$ & $\mathrm{MR}=\mathrm{a} \exp (-\mathrm{k} \theta)+(1-\mathrm{a}) \exp (-\mathrm{k} \mathrm{b} \theta)$ & $(2)$ \\
Two terms & $\mathrm{MR}=\mathrm{a} \exp \left(-\mathrm{k}_{0} \theta\right)+\mathrm{b} \exp \left(-\mathrm{k}_{1} \theta\right)$ & $(3)$ \\
Two-term exponential & $\mathrm{MR}=\mathrm{a} \exp (-\mathrm{k} \theta)+(1-\mathrm{a}) \exp (-\mathrm{k} \mathrm{a} \theta)$ & $(4)$ \\
Henderson and Pabis & $\mathrm{MR}=\mathrm{a} \exp (-\mathrm{k} \theta)$ & $(5)$ \\
Logarithmic & $\mathrm{MR}=\mathrm{a} \exp (-\mathrm{k} \theta)+\mathrm{c}$ & $(6)$ \\
Midilli & $\mathrm{MR}=\mathrm{a} \exp \left(-\mathrm{k} \theta^{n}\right)+\mathrm{b} \theta$ & $(7)$ \\
Newton & $\mathrm{MR}=\exp (-\mathrm{k} \theta)$ & $(8)$ \\
Page & $\mathrm{MR}=\exp \left(-\mathrm{k} \theta^{n}\right)$ & $(9)$ \\
\hline
\end{tabular}

$\theta$ - Drying time, $h ; k, k_{o}, k_{1}$ - Drying constants, $h^{-1} ; \mathrm{a}, \mathrm{b}, \mathrm{c}, \mathrm{n}$ - Coefficients of the models

The moisture reduction rate (MRR) during leaf drying was determined by Eq. 10, as described by Corrêa et al. (2001). The same authors define MRR as the amount of water lost by a given product per unit of dry matter per unit of time.

$$
\operatorname{MRR}=\frac{\mathrm{Mw}_{0}-\mathrm{Mw}_{\mathrm{i}}}{\operatorname{DM}\left(\mathrm{t}_{\mathrm{i}}-\mathrm{t}_{0}\right)}
$$

where:

MRR - moisture reduction rate, $\mathrm{kg} \mathrm{kg}^{-1} \mathrm{~h}^{-1}$;

$\mathrm{Mw}_{0}$ - previous total mass of water, $\mathrm{kg}$;

$\mathrm{Mw}_{\mathrm{i}}$ - current total mass of water, $\mathrm{kg}$;

DM - dry matter, kg;

$\mathrm{t}_{0} \quad$ - previous total drying time, $\mathrm{h}$; and, $t_{i} \quad$ - current total drying time, $h$.

The effective diffusion coefficients of the leaves were obtained by fitting the mathematical model of liquid diffusion (Eq. 11) to the data observed during drying under different air conditions.

$M R=\frac{M-M_{e}}{M_{i}-M_{e}}=\frac{8}{\pi^{2}} \sum_{n_{t}=0}^{\infty} \frac{1}{\left(2 n_{t}+1\right)^{2}} \exp \left[-\left(2 n_{t}+1\right)^{2} \pi^{2} D_{i}\left(\frac{\theta}{4 L}\right)^{2}\right]$

where:

$\mathrm{D}_{\mathrm{i}} \quad$ - effective diffusion coefficient, $\mathrm{m}^{2} \mathrm{~s}^{-1}$;

$\mathrm{L}$ - product thickness, $\mathrm{m}$; and,

$n_{t} \quad$ - number of terms to be used in the model.

Leaf thickness (L) was obtained using a digital caliper, with resolution of $0.01 \mathrm{~mm}$, by measuring the thickness of 50 leaves, performing six measurements at different points of each leaf. After the measurements, the average thickness of jurubeba leaves was calculated, which was $0.939 \mathrm{~mm}$.

The effect of temperature on the effective diffusion coefficient was evaluated using the Arrhenius equation, as described in Eq. 12.

$$
\mathrm{D}_{\mathrm{i}}=\mathrm{D}_{0} \exp \left(\frac{\mathrm{E}_{\mathrm{a}}}{\mathrm{R} \mathrm{T}_{\mathrm{a}}}\right)
$$

where:

$\mathrm{D}_{\mathrm{o}} \quad$ - pre-exponential factor;

$\mathrm{E}_{\mathrm{a}} \quad$ - activation energy, $\mathrm{kJ} \mathrm{mol}^{-1}$;

$\mathrm{R}$ - universal gas constant, $8.314 \mathrm{~kJ} \mathrm{kmol}^{-1} \mathrm{~K}^{-1}$; and,

$\mathrm{T}_{\mathrm{a}}$ - absolute temperature, $\mathrm{K}$.

The mathematical models (Table 1) were fitted to the observed moisture ratio data obtained during the drying of jurubeba leaves under the different drying air conditions, using a statistical program.

In order to select the regression model to represent the drying process of the leaves under all drying air conditions, the degree of fit of each model was evaluated based on the values of the relative mean error $(\mathrm{P})$, which indicate the deviation between the observed data and the values estimated by the mathematical model under study (Kashaninejad et al., 2007). Another index also used was the standard deviation of the estimate (SE), which indicates the potential of a model to reliably describe a given physical process; the lower its value, the better the quality of the fit of the model to the data obtained experimentally (Draper \& Smith, 1998). In addition, the values of the adjusted coefficient of determination $\left(R^{2}\right)$ were analyzed.

$\mathrm{P}$ and SE values were calculated using Eqs. 13 and 14, respectively.

$$
\mathrm{P}=\frac{100}{\mathrm{n}_{0}} \sum_{\mathrm{i}=1}^{\mathrm{n}_{0}}\left(\frac{|\mathrm{Y}-\hat{\mathrm{Y}}|}{\mathrm{Y}}\right)
$$




$$
\mathrm{SE}=\sqrt{\frac{\sum_{\mathrm{i}=1}^{\mathrm{n}_{0}}(\mathrm{Y}-\hat{\mathrm{Y}})^{2}}{\mathrm{DF}}}
$$

where:

$$
\begin{array}{ll}
\mathrm{n}_{\mathrm{o}} & \text { - number of experimental observations; } \\
\mathrm{Y} & \text { - experimentally observed value; } \\
\mathrm{Y} & \text { - model-estimated value; and, } \\
\mathrm{DF} & \text { - residual degrees of freedom. }
\end{array}
$$

Another selection criterion adopted was the choice of a model that satisfactorily fitted to all drying air conditions evaluated in this study.

\section{Results AND Discussion}

Considering the mathematical models with relative mean errors (P) below $10 \%$ as adequate to accurately estimate the data observed during drying (Mohapatra \& Rao, 2005), the only model that can be used to represent the drying process of jurubeba leaves for all drying air conditions evaluated in the present study is the Midilli model (7), because it is the only one that meets this criterion for all drying air conditions (Table 2).

The other statistical indices analyzed, standard deviation of the estimate (SE) and coefficient of determination $\left(\mathrm{R}^{2}\right)$, corroborate the choice of the Midilli model (7) based on the $P$ values because, for all drying air conditions it has low values of SE (Table 2). In addition, the selected model has $\mathrm{R}^{2}$ values greater than 0.99 for all drying air conditions, which indicates a satisfactory representation of the process under study by the model, according to Kashaninejad et al. (2007).

Therefore, the Midilli model was selected to represent the drying process of jurubeba leaves. Alves et al. (2017), Gasparin et al. (2017) and Martins et al. (2018), in studies similar to the present study, working with leaves of Hyptis suaveolens, Mentha piperita and Morus nigra L. respectively, studied the drying kinetics of these medicinal plants at different drying air temperatures and speeds and also verified that the Midilli model was the one that best fitted to the observed data for all drying air conditions.

The Midilli model is usually the one that best fits to drying of leaves of medicinal plants, as it has already been verified for various products, such as for Petroselinum crispum Mill. leaves (Corrêa Filho et al., 2018), Cymbopogon citratus leaves (Gomes et al., 2017), Maytenus ilicifolia (Schrad.) Planch leaves (Melo et al., 2016), Genipa americana L. leaves (Silva et al., 2015), Schinus terebinthifolius leaves (Goneli et al., 2014), and Ocimum basilicum leaves (Reis et al., 2012).

According to Goneli et al. (2014), the best fit of the Midilli model to the drying curves of leaves of medicinal plants is probably due to the rapid loss of water at the beginning of the drying process of these products, generating a drying curve that is steeper and mathematically better characterized by this model.

The values of moisture ratio values estimated by the Midilli model showed high correspondence to the moisture ratio data

\begin{tabular}{|c|c|c|c|c|c|c|}
\hline \multirow[b]{2}{*}{ Models } & \multicolumn{3}{|c|}{$0.4 \mathrm{~m} \mathrm{~s}^{-1}$} & \multicolumn{3}{|c|}{$0.8 \mathrm{~m} \mathrm{~s}^{-1}$} \\
\hline & $\begin{array}{c}\text { SE } \\
\text { (decimal) }\end{array}$ & $\begin{array}{c}P \\
(\%)\end{array}$ & $\begin{array}{c}\mathbf{R}^{2} \\
\text { (decimal) }\end{array}$ & $\begin{array}{c}\text { SE } \\
\text { (decimal) }\end{array}$ & $\begin{array}{c}P \\
(\%)\end{array}$ & $\begin{array}{c}\mathbf{R}^{2} \\
\text { (decimal) }\end{array}$ \\
\hline & \multicolumn{6}{|c|}{$40^{\circ} \mathrm{C}$} \\
\hline (2) & 0.0093 & 8.8345 & 0.9990 & 0.0115 & 16.4795 & 0.9985 \\
\hline (3) & 0.0127 & 8.3076 & 0.9982 & 0.0133 & 15.9012 & 0.9980 \\
\hline (4) & 0.0238 & 14.2545 & 0.9933 & 0.0211 & 16.0521 & 0.9948 \\
\hline (5) & 0.0125 & 8.3076 & 0.9982 & 0.0131 & 15.9011 & 0.9980 \\
\hline (6) & 0.0108 & 2.4261 & 0.9986 & 0.0089 & 1.9925 & 0.9991 \\
\hline (7) & 0.0079 & 4.1558 & 0.9993 & 0.0077 & 5.1333 & 0.9993 \\
\hline (8) & 0.0262 & 6.5621 & 0.9918 & 0.0212 & 12.7115 & 0.9946 \\
\hline \multirow[t]{2}{*}{ (9) } & 0.0186 & 13.0268 & 0.9959 & 0.0183 & 19.0976 & 0.9961 \\
\hline & \multicolumn{6}{|c|}{$50^{\circ} \mathrm{C}$} \\
\hline (2) & 0.0092 & 5.7305 & 0.9990 & 0.0035 & 1.9637 & 0.9998 \\
\hline (3) & 0.0050 & 1.5168 & 0.9997 & 0.0036 & 1.9637 & 0.9998 \\
\hline (4) & 0.0065 & 2.2654 & 0.9995 & 0.0118 & 4.0493 & 0.9981 \\
\hline (5) & 0.0091 & 5.6153 & 0.9990 & 0.0100 & 3.0464 & 0.9986 \\
\hline (6) & 0.0054 & 3.2004 & 0.9996 & 0.0097 & 1.7719 & 0.9988 \\
\hline (7) & 0.0055 & 2.5595 & 0.9996 & 0.0075 & 3.1253 & 0.9993 \\
\hline (8) & 0.0089 & 5.7305 & 0.9990 & 0.0156 & 6.1875 & 0.9966 \\
\hline (9) & 0.0076 & 3.3022 & 0.9993 & 0.0086 & 2.8367 & 0.9990 \\
\hline & \multicolumn{6}{|c|}{$60^{\circ} \mathrm{C}$} \\
\hline (2) & 0.0171 & 7.2059 & 0.9964 & 0.0153 & 14.5289 & 0.9974 \\
\hline (3) & 0.0173 & 7.4362 & 0.9965 & 0.0118 & 6.2663 & 0.9985 \\
\hline (4) & 0.0185 & 12.4489 & 0.9957 & 0.0142 & 12.3597 & 0.9976 \\
\hline (5) & 0.0182 & 13.8396 & 0.9958 & 0.0147 & 14.4260 & 0.9974 \\
\hline (6) & 0.0180 & 9.6815 & 0.9961 & 0.0130 & 8.2811 & 0.9981 \\
\hline (7) & 0.0170 & 5.5921 & 0.9967 & 0.0112 & 4.3142 & 0.9987 \\
\hline (8) & 0.0183 & 14.2051 & 0.9956 & 0.0144 & 14.5289 & 0.9974 \\
\hline \multirow[t]{2}{*}{ (9) } & 0.0185 & 13.2689 & 0.9957 & 0.0146 & 13.8692 & 0.9975 \\
\hline & \multicolumn{6}{|c|}{$70^{\circ} \mathrm{C}$} \\
\hline (2) & 0.0717 & 31.1662 & 0.9677 & 0.0102 & 6.6472 & 0.9993 \\
\hline (3) & 0.0282 & 20.8136 & 0.9967 & 0.0160 & 6.8101 & 0.9985 \\
\hline (4) & 0.0108 & 6.5752 & 0.9991 & 0.0095 & 6.6509 & 0.9993 \\
\hline (5) & 0.0213 & 18.5044 & 0.9967 & 0.0135 & 6.8101 & 0.9985 \\
\hline (6) & 0.0155 & 15.5468 & 0.9985 & 0.0130 & 8.3973 & 0.9988 \\
\hline (7) & 0.0137 & 9.8979 & 0.9992 & 0.0114 & 4.8820 & 0.9993 \\
\hline (8) & 0.0213 & 20.0957 & 0.9962 & 0.0131 & 7.0620 & 0.9984 \\
\hline (9) & 0.0118 & 7.3865 & 0.9991 & 0.0100 & 6.5022 & 0.9992 \\
\hline
\end{tabular}
observed for the different drying air conditions of jurubeba
Table 2. Values of the statistical indices obtained in the modeling of the drying curves of jurubeba leaves for each drying air speed

leaves (Figure 2), thus reinforcing the good fit and applicability of this model to represent the studied process.

For jurubeba leaves to reach the moisture content of approximately 0.11 (decimal, d.b.), at the drying air speed of $0.4 \mathrm{~m} \mathrm{~s}^{-1}, 12.33,3.17,2.00$ and $0.75 \mathrm{~h}$ (Figure 2A) were required for air temperatures of $40,50,60$ and $70{ }^{\circ} \mathrm{C}$, respectively. For the drying air speed of $0.8 \mathrm{~m} \mathrm{~s}^{-1}, 10.33,2.67,1.58$, and $0.67 \mathrm{~h}$ (Figure $2 \mathrm{~B}$ ) were required for the same drying air temperatures mentioned above.

The reduction in drying time with the increase in drying air temperature was already expected (Figure 2), a behavior observed in several studies with medicinal plants (Goneli et al., 2014; Melo et al., 2016; Gomes et al., 2017; Silva et al., 2017; Corrêa Filho et al., 2018). The drying time for jurubeba leaves to reach the final moisture content was also reduced by increasing the drying air speed, a behavior observed by Martins et al. (2018) with Morus nigra L. leaves and by Alves et al. (2017) with Hyptis suaveolens leaves.

The drying air speed is one of the factors that influence the mass and heat transfer coefficients. Therefore, the increase in air speed increases the coefficients of mass and heat transfer between the air and the product, intensifying the transfer of 
A.

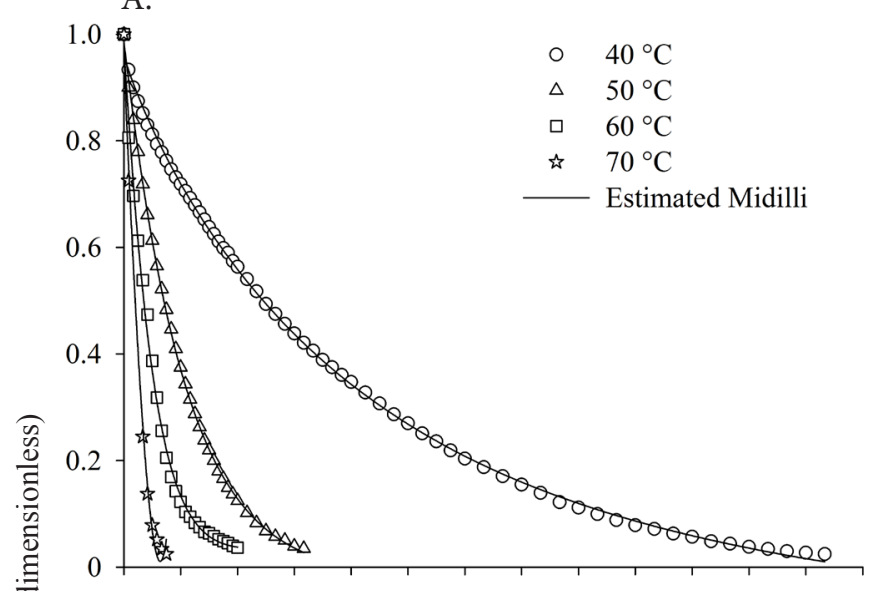

B.

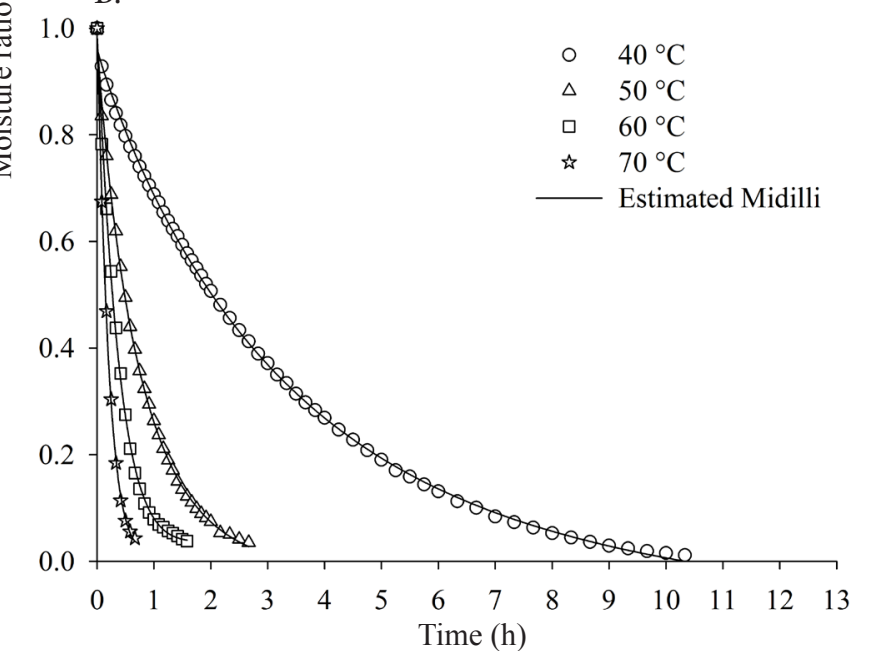

Figure 2. Moisture ratio values observed and estimated by the Midilli model for the drying of jurubeba (Solanum paniculatum L.) leaves at air speeds of $0.4 \mathrm{~m} \mathrm{~s}^{-1}(\mathrm{~A})$ and $0.8 \mathrm{~m} \mathrm{~s}^{-1}(\mathrm{~B})$

mass from the leaves to their surroundings per unit of time, which consequently reduces the drying time (Shahhoseini et al., 2013).

Air temperature had more pronounced effect than air speed on the reduction of the drying time for jurubeba leaves to reach the moisture content of approximately 0.11 (decimal, d.b.) (Figure 2). As explained by Martins (2015), this occurs because the main factor to trigger the drying process of agricultural products is the difference of vapor pressure between the drying air and the product. Vapor pressure is directly influenced by temperature because the increase in drying air temperature increases the difference of vapor pressure between the air and the product, while the drying air displacement speed does not affect the vapor pressure between the air and the product.

The removal of water from jurubeba leaves was more intense at the beginning of the drying process (Figure 3), because the higher the drying air temperature, the higher the moisture reduction rate (MRR) at the beginning of the process. After $1 \mathrm{~h}$ of drying, the MRR, for both drying air velocities, did not differ significantly as a function of drying air temperature.

For the same temperature, at the beginning of the drying process, as the air speed increases, there is an increment in MRR (Figure 3). According to Babalis et al. (2006), this phenomenon is explained by the fact that, at the beginning of the drying process, water evaporates from the surface of the product, causing the air
A.

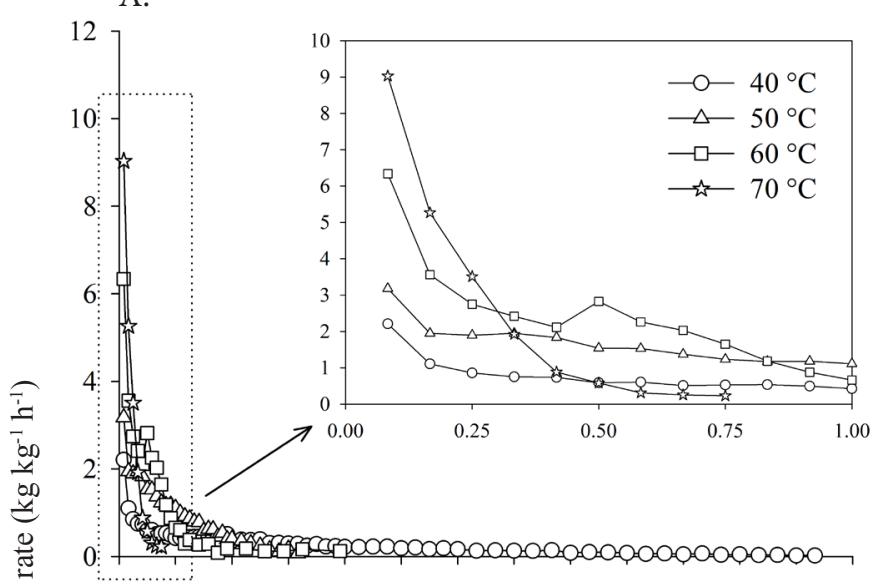

B.

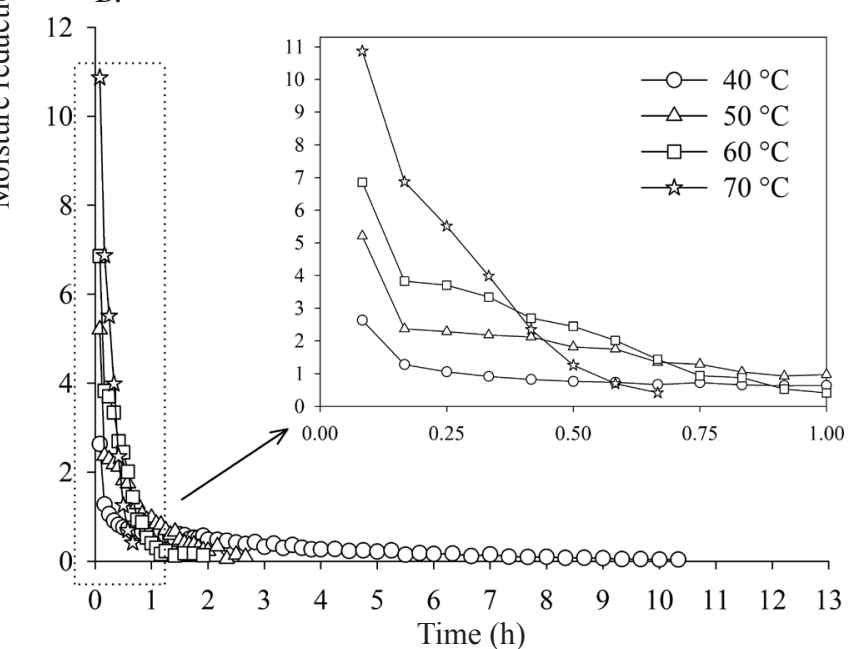

Figure 3. Moisture reduction rate for jurubeba (Solanum paniculatum $\mathrm{L}$.) leaves during the drying process at air speeds of $0.4 \mathrm{~m} \mathrm{~s}^{-1}(\mathrm{~A})$ and $0.8 \mathrm{~m} \mathrm{~s}^{-1}(\mathrm{~B})$

speed to contribute with greater intensity to water removal at this stage of the process. In the course of the drying process, water evaporation from the surface of the product is gradually replaced by the condensation that moves into the product, reducing the effect of air speed, causing liquid diffusion to become the most important factor in this process.

Regarding the effect of air speed on the drying of jurubeba leaves, Figure 2 shows that the effect of air speed on drying time was more evident at the lowest drying air temperature $\left(40^{\circ} \mathrm{C}\right)$.

As the drying air temperature increased, there was an increment in the drying constant $\mathrm{k}$ of the Midilli model, for the drying of jurubeba leaves, regardless of the drying air speed (Table 3). According to Babalis \& Belessiotis (2004), the drying constant $\mathrm{k}$ can be used as an approximation to characterize the effect of the drying air condition (air temperature and speed) and is correlated with the effective diffusion in the drying process.

It can be observed that, for the same drying air temperature, at the drying air speed of $0.8 \mathrm{~m} \mathrm{~s}^{-1}$, the drying constant $\mathrm{k}$ always has values higher than at the air speed of $0.4 \mathrm{~m} \mathrm{~s}^{-1}$ (Table 3 ). This is because this parameter is associated with water diffusion during the drying process and, at higher drying air speed, the diffusion coefficient of jurubeba leaves was also higher.

The values of the effective diffusion coefficient $\left(D_{i}\right)$ of jurubeba leaves increased as the drying air temperature 
Table 3. Midilli model parameters and effective diffusion coefficient $\left(D_{i} \times 10^{-11} \mathrm{~m}^{2} \mathrm{~s}^{-1}\right)$ for the different air temperatures and speeds in the drying of jurubeba leaves (Solanum paniculatum L.)

\begin{tabular}{|c|c|c|c|c|c|c|c|c|c|c|}
\hline \multirow{2}{*}{$\begin{array}{c}\text { Temperature } \\
\left({ }^{\circ} \mathrm{C}\right)\end{array}$} & \multicolumn{5}{|c|}{$0.4 \mathrm{~m} \mathrm{~s}^{-1}$} & \multicolumn{5}{|c|}{$0.8 \mathrm{~m} \mathrm{~s}^{-1}$} \\
\hline & $\mathbf{a}$ & k & $n$ & b & $\overline{D_{i}}$ & $\mathbf{a}$ & k & $n$ & b & $\overline{D_{i}}$ \\
\hline 40 & 0.9623 & 0.2842 & 0.8928 & -0.0046 & 2.0966 & 0.9620 & 0.3284 & 0.9366 & -0.0050 & 2.5880 \\
\hline 50 & 0.9855 & 0.9648 & 1.0312 & -0.0045 & 7.9232 & 0.9858 & 1.3120 & 0.9213 & -0.0041 & 10.8971 \\
\hline 60 & 0.9743 & 2.0835 & 1.0730 & 0.0126 & 16.0276 & 0.9875 & 2.7598 & 1.0652 & 0.0182 & 20.5583 \\
\hline 70 & 0.9983 & 5.0182 & 1.1186 & -0.0132 & 37.8640 & 0.9973 & 5.4893 & 1.0819 & 0.0118 & 39.4700 \\
\hline
\end{tabular}

increased (Table 3), for both air velocities. For the same air temperature, as the drying air speed increased, there was an increment in the $\mathrm{D}_{\mathrm{i}}$ values of jurubeba leaves. Similar behavior, as a function of drying air temperature and speed, for the $\mathrm{D}_{\mathrm{i}}$ of leaves of medicinal plants has been observed by Alves et al. (2017) and Martins et al. (2018).

The increase in $\mathrm{D}_{\mathrm{i}}$, as a function of the increase in drying air temperature occurs because, as the value of this air parameter increases, there is a reduction in the viscosity of water and an increase in the vibration level of its molecules in the product, which consequently affects the diffusion in the capillaries of the product (Goneli et al., 2009), favoring the movement of water in jurubeba leaves. On the other hand, the increase in $\mathrm{D}_{\mathrm{i}}$ values as a function of the increase in drying air speed, according to Martins (2015), can be attributed to the fact that the increase in drying air speed contributes to the evaporation of water from the surface of the product.

The activation energy, obtained by means of the coefficients of the Arrhenius equation fitted to the $D_{i}$ values for jurubeba leaves during drying, calculated according to Eq. 12, was equal to 84.07 and $79.09 \mathrm{~kJ} \mathrm{~mol}^{-1}$ for leaves dried at drying air speeds of 0.4 and $0.8 \mathrm{~m} \mathrm{~s}^{-1}$, respectively, for the drying air temperature range from 40 to $70{ }^{\circ} \mathrm{C}$.

With the increase in drying air speed, there was a reduction in the values of activation energy, a phenomenon observed by Alves et al. (2017) for Hyptis suaveolens leaves. According to Kashaninejad et al. (2007), the activation energy is a barrier that must be overcome so that the diffusion process can be triggered in the product. Also, according to Faria et al. (2012) and Morais et al. (2013), the lower the activation energy, the higher the diffusivity of water in the product during the drying process, a fact observed in the present study, in which as the drying air speed increased, higher values of $\mathrm{D}_{\mathrm{i}}$ (Table 3 ) and lower activation energy were obtained. For Martins (2015), the increase in drying air speed facilitates the evaporation of water from the product, which leads to an increase in $\mathrm{D}_{\mathrm{i}}$ and a reduction in the activation energy.

The values of activation energy calculated for jurubeba leaves were higher than those found for other leaves of medicinal plants dried at different air temperatures and velocities, 62.513 and $61.289 \mathrm{~kJ} \mathrm{~mol}^{-1}$ for leaves of Hyptis suaveolens (Alves et al., 2017), 65.94 and $66.08 \mathrm{~kJ} \mathrm{~mol}^{-1}$ for leaves of Morus nigra L. (Martins et al., 2018) and 68.42 and $78.27 \mathrm{~kJ} \mathrm{~mol}^{-1}$ for leaves of Mentha piperita (Gasparin et al., 2017).

\section{Conclusions}

1. Among the statistical models fitted to predict the drying of jurubeba leaves, only the Midilli model fitted satisfactorily to all drying air conditions.
2. With the increase in air temperature and speed there was reduction in the drying time of jurubeba leaves. Air temperature had more intense effect on the reduction of drying time, while air speed had more pronounced effect on reducing drying time at air temperature of $40^{\circ} \mathrm{C}$.

3. The values of the effective diffusion coefficient increased with the increment in drying air temperature and speed.

4. For the air temperature range from 40 to $70{ }^{\circ} \mathrm{C}$, as the drying air speed increased, the activation energy for drying jurubeba leaves was reduced.

\section{ACKNOWLedgments}

The authors thank Fundação de Apoio ao Desenvolvimento do Ensino, Ciência e Tecnologia do Estado do Mato Grosso do Sul (FUNDECT), Conselho Nacional de Desenvolvimento Científico e Tecnológico (CNPq) and Coordenação de Aperfeiçoamento de Pessoal de Nível Superior (CAPES) for the financial support to conduct and publish this study.

\section{Literature Cited}

Alves, J. J. L.; Resende, O.; Oliveira, D. E. C. de; Branquinho, N. A. de A. Cinética de secagem das folhas de Hyptis suaveolens. Revista Brasileira de Plantas Medicinais, v.19, p.168-176, 2017.

ASABE - American Society of Agricultural and Biological Engineers. Moisture measurement - forages: Standard S358.2 DEC1988, R2008. St. Joseph: ASABE, 2010. p.684-685.

Babalis, S. J.; Belessiotis, V. G. Influence of the drying condition on the drying constants and moisture diffusivity during the thin-layer drying of figs. Journal of Food Engineering, v.65, p.449-458, 2004. https://doi.org/10.1016/j.jfoodeng.2004.02.005

Babalis, S. J.; Papanicolaou, E.; Kyriakis, N.; Belessiotis, V. G. Evaluation of thin-layer drying models for describing drying kinetics of figs (Ficus carica). Journal of Food Engineering, v.75, p.205-214, 2006. https://doi.org/10.1016/j. jfoodeng.2005.04.008

Corrêa, P. C.; Machado, P. F.; Andrade, E. T. Cinética de secagem e qualidade de grãos de milho-pipoca. Ciência e Agrotecnologia, v.25, p.134-142, 2001.

Corrêa Filho, L. C.; Martinazzo, A. P.; Teodoro, C. E. de S.; Andrade, E. T. de. Post-harvest of parsley leaves (Petroselinum crispum): Mathematical modelling of drying and sorption processes. Revista Brasileira de Engenharia Agrícola e Ambiental, v.22, p.131-136, 2018. https://doi.org/10.1590/1807-1929/agriambi. v22n2p131-136

Draper, N. R.; Smith, H. Applied regression analysis. 3.ed. New York: John Wiley \& Sons, 1998. 712p. https://doi. org/10.1002/9781118625590 
Faria, R. Q. de; Teixeira, I. R.; Devilla, I. A.; Ascheri, D. P. R.; Resende, O. Cinética de secagem de sementes de crambe. Revista Brasileira de Engenharia Agrícola e Ambiental, v.16, p.573-583, 2012. https://doi.org/10.1590/S1415-43662012000500014

Gasparin, P. P.; Alves, N. C. C.; Christ, D.; Coelho, S. R. M. Qualidade de folhas e rendimento de óleo essencial em hortelã pimenta (Mentha x Piperita L.) submetida ao processo de secagem em secador de leito fixo. Revista Brasileira de Plantas Medicinais, v.16, p.337-344, 2014. https://doi.org/10.1590/1983084X/12_003

Gasparin, P. P.; Christ, D.; Coelho, S. R. M. Secagem de folhas Mentha piperita em leito fixo utilizando diferentes temperaturas e velocidades de ar. Revista Ciência Agronômica, v.48, p.242250, 2017.

Gomes, N. H. F.; Silva Neto, H. C. da; Alves, J. J. L.; Rodovalho, R. S.; Sousa, C. M. Cinética de secagem de folhas de Cymbopogon citratus. Engevista, v.19, p.328-338, 2017. https://doi.org/10.22409/ engevista.v19i2.837

Goneli, A. L. D.; Corrêa, P. C.; Afonso Júnior, P. C.; Oliveira, G. H. H. Cinética de secagem dos grãos de café descascados em camada delgada. Revista Brasileira de Armazenamento, v.especial, p.6473, 2009.

Goneli, A. L. D.; Vieira, M. do C.; Vilhasanti, H. da C. B.; Gonçalves, A. A. Modelagem matemática e difusividade efetiva de folhas de aroeira durante a secagem. Pesquisa Agropecuária Tropical, v.44, p.56-64, 2014. https://doi.org/10.1590/S1983-40632014000100005

Karami, H.; Rasekh, M.; Darvishi, Y.; Khaledi, R. Effect of drying temperature and air velocity on the essential oil content of Mentha aquatica L. Journal of Essential Oil Bearing Plants, v.20, p.11311136, 2017. https://doi.org/10.1080/0972060X.2017.1371647

Kashaninejad, M.; Mortazavi, A.; Safekordi, A.; Tabil, L. G. Thin-layer drying characteristics and modeling of pistachio nuts. Journal of Food Engineering, v.78, p.98-108, 2007. https://doi.org/10.1016/j. jfoodeng.2005.09.007

Lorenzi, H.; Matos, F. J. A. Plantas medicinais no Brasil: Nativas e exóticas. 2.ed. Nova Odessa: Instituto Plantarum de Estudos da Flora Ltda, 2008. 544p.

Martins, E. A. S. Dimensionamento e experimentação de um secador de leito fixo para a secagem de produtos agrícolas. Dourados: UFGD, 2015. 123p. Dissertação Mestrado

Martins, E. A. S.; Goneli, A. L. D.; Goncalves, A. A.; Hartmann Filho, C. P.; Siqueira, V. C.; Oba, G. C. Drying kinetics of blackberry leaves. Revista Brasileira de Engenharia Agrícola e Ambiental, v.22, p.570-576, 2018. https://doi.org/10.1590/1807-1929/ agriambi.v22n8p570-576
Melo, R. M.; Siqueira, V. C.; Silva, F. P. D.; Martins, E. A. S.; Goneli, A. L. D.; Vieira, M. C. Cinética de secagem de folhas de espinheirasanta [Maytenus ilicifolia (Schrad.) Planch]. Revista Brasileira de Plantas Medicinais, v.18, p.819-827, 2016.

Mohapatra, D.; Rao, P. S. A thin layer drying model of parboiled wheat. Journal of Food Engineering, v.66, p.513-518, 2005. https://doi. org/10.1016/j.jfoodeng.2004.04.023

Morais, S. J. S. da; Devilla, I. A.; Ferreira, D. A.; Teixeira, I. R. Modelagem matemática das curvas de secagem e coeficiente de difusão de grãos de feijão-caupi [Vigna unguiculata (L.) Walp.]. Revista Ciência Agronômica, v.44, p.455-463, 2013. https://doi. org/10.1590/S1806-66902013000300006

Reis, R. C. dos; Devilla, I. A.; Ascheri, D. P. R.; Servulo, A. C. O.; Souza, A. B. M. Cinética de secagem de folhas de manjericão (Ocimum basilicum L.) via infravermelho. Revista Brasileira de Engenharia Agrícola e Ambiental, v.16, p.1346-1352, 2012. https:// doi.org/10.1590/S1415-43662012001200012

Shahhoseini, R.; Ghorbani, H.; Karimi, S. R.; Estaji, A.; Moghaddam, M. Qualitative and quantitative changes in the essential oil of Lemon Verbena (Lippia citriodora) as affected by drying condition. Drying Technology, v.31, p.1020-1028, 2013. https:// doi.org/10.1080/07373937.2013.771649

Silva, F. P. da; Siqueira, V. C.; Martins, E. A. S.; Miranda, F. M. N.; Melo, R. M. Termodynamic properties and drying kinetics of Bauhinia forfcata Link leaves. Revista Brasileira de Engenharia Agrícola e Ambiental, v.21, p.61-67, 2017. https://doi.org/10.1590/18071929/agriambi.v21n1p61-67

Silva, L. A.; Resende, O.; Virgolino, Z. Z.; Bessa, J. F. V.; Morais, W. A.; Vidal, V. M. Cinética de secagem e difusividade efetiva em folhas de jenipapo (Genipa americana L.). Revista Brasileira de Plantas Medicinais, v.17, p.953-963, 2015. https://doi.org/10.1590/1983084X/14_106

Soares, R. D.; Chaves, M. A.; Silva, A. A. L. da; Silva, M. V. da; Souza, B. dos S. Influência da temperatura e velocidade do ar na secagem de manjericão (Ocimum basilicum L.) com relação aos teores de óleos essenciais e de linalol. Ciência e Agrotecnologia, v.31, p.11081113, 2007. https://doi.org/10.1590/S1413-70542007000400025

Terço, J. W. dos S.; Lima, R. A. Identificação das classes de metabólitos secundários no extrato etanólico dos frutos e folhas de Solanum paniculatum L. South American Journal of Basic Education, Technical and Technological, v.3, p.92-99, 2016.

Vieira Júnior, G. M.; Rocha, C. Q. da; Rodrigues, T. de S.; HirumaLima, C. A.; Vilegas, W. New steroidal saponins and antiulcer activity from Solanum paniculatum L. Food Chemistry, v.186, p.160-167, 2015. https://doi.org/10.1016/j.foodchem.2014.08.005 